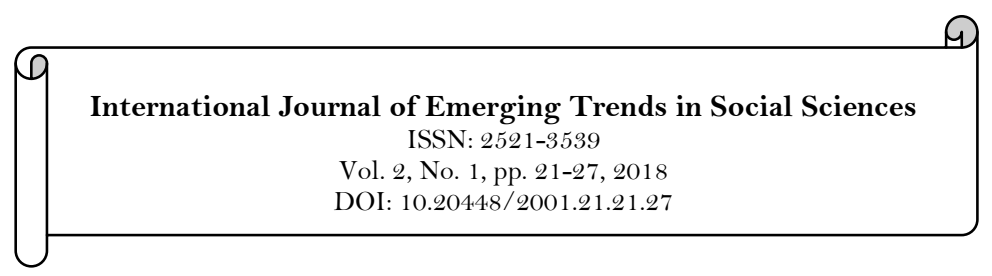

\title{
Exploring Curriculum Innovation as a Tool Towards Attainment of Self Reliance of NCE Graduates of Islamic Studies
}

\author{
Agbabiaka-Mustapha, Muinat ${ }^{1}$ \\ Kazeem Sirajudeen Adebola ${ }^{2}$ \\ 1,2 Islamic Studies Department Michael Otedola College of Primary Education, Noforija Epe Lagos - Nigeria. \\ ${ }^{2}$ Email:biolabiaka@yahoo.com
}

\begin{abstract}
Islamic Studies is offered from the primary level of education to the tertiary level of education in Nigeria and have contributed a lot to the development of knowledge in the world by producing great scholars in various fields of knowledge such as $\mathrm{Al}$ kindi, Ibn khaldun, and $\mathrm{Al}-$ Ghazali, Al-Razi, to mention but a few. Islamic education was the first to introduce a formal, organized and certificated education which provided job opportunities as its products were equipped with skills needed in the management of various affairs of man. In recent time graduates of Islamic Studies are becoming irrelevant in the knowledge economy and finding it difficult to attain self reliance. This paper examines the factors that is hindering Islamic Studies graduates from attaining self reliance and which includes irrelevance curriculum content, low enrolment, inadequate teaching and learning materials, lack of skill development in the application of information and communication in technology, admission criteria, methods of delivery, lack of proper funding, poor attitudes of lecturers to research among others. This study is literature survey and data is presented based on direct deductions from the available documents. The study reveals that the present Islamic Studies curriculum content is inadequate to enhance the attainment of self reliance among Islamic Studies graduates. The study recommends the need for curriculum innovation in Islamic Studies by integrating sciences, and vocational courses that can enhance the attainment of self reliance among graduates of Islamic Studies.
\end{abstract}

\author{
Keywords: \\ Exploration \\ Curriculum innovation \\ Islamic studies \\ Attainment \\ Self reliance.
}

Licensed:

This work is licensed under a Creative

Commons Attribution 4.0 License.

Publisher:

Scientific Publishing Institute

\section{Introduction}

Education is the bedrock upon which the development of any nation is built and it is also known as one of the most powerful weapons for reducing poverty and inequality in modern societies. The reason is that education is targeted at one end result which is providing good jobs to citizens to enable them to earn a living and make significant and meaningful contributions to the society.

One of the main goals of tertiary education as enunciated in the National Policy on education is the acquisition of both physical and intellectual skills which will enable individual to be self reliant and useful members of the society (Federal Republic of Nigeria, 2014). The Islamic System of education embodies a general and comprehensive concept which sustains a unique and distinctive educational policy. It is clear, therefore, that Islam is not merely a religion but a complete way of life which comprehensively encompasses all aspect of Muslim life. Therefore the Islamic oriented system of education can simply be seen as a system founded on the basic of Tawhid (monotheism - oneness of Allah) which guides mankind towards living a happy, prosperous, productive and revolutionary life in this world as well as happier, blissful and successful life in the hereafter (Abdulhamid, 2017).

Islamic System of education have contributed a lot to the development of knowledge in the world and empowered people in various aspects of life by producing notable and great scholars in different works of life. Alkindi, was the first Arab philosopher, thus it may be justifiably claimed that as Descartes was the father of modern philosophy, Alkindi was the father of Arabic philosophy. Al-Razi was a celebrated Muslim physician, physicist, alchemist and phychologist. 
Al Farabi was the first Turkish philosopher to make name being a great expositor to Aristotle's logic, he was called "Al-mu'alliml-thani (the second Teacher)", i.e the second Aristotle. Ibn sina or Aucienna was an encyclopedist, physiologist, physician, mathematician, astronomer and poet. According to George Sarton, he is the most famous scientists and philosopher of Islam and one of the greatest of all races, places and times. Ibn Khaldun was a Muslim historian, philosopher, economist politician and pedagogue. Above all he was the father of the science of history, and one of the founders of sociology.

Al-Ghazali was one of the greatest original thinkers, not only in the history of Muslim philosophy, but also in the history of human thought. According to MacDonald, he is the equal of Augustine in the philosophical and theological disciplines (Sheikh, 1997).

Babarinde and Bankole (2011) assert that the fortune of Islamic education in Nigeria is better measured by its positive impact on various facets of life of West Africans in general because for the first time in the life of the Nigerians, Islam introduced a formal, organized, programmed and certificated education which provided job opportunities for its products were equipped with skills needed in the management of the various affairs of man. He however, lamented that the advent of the colonial rulers in the $19^{\text {th }}$ century, C. E. change the fortune of Islamic education.

In concordance with the opinion of Bidmos as highlighted above, it is observed that in the recent time of knowledge - economy, industries and other sector of the economy cannot employ graduates of Islamic Studies as a result of irrelevant of curriculum to societal needs and which Babarinde and Bankole (2011) rightly captured thus:

"the form of Islamic education practiced in Nigeria is criticized for not measuring up to the standard of Islamic education in the centre of Islamic civilization such as Damascus, Baghdad Kufah, Cairo and Turkey where emphasis was placed on philosophy, calligraphy, mathematics and other Sciences including medicine and technology"

In view of the above, the significance of this study lies in its resolve at addressing the problem associated with job prospects that can enhance the attainment of the self reliance among the graduates of Islamic Studies so that they can be relevant in the knowledge based economy and compete favourably with other disciplines in the globalised world.

Moreover, religion plays a significant role in history and society. Study of religion is essential to understanding both the nation and the world and the development of human soul. However, omission of facts about religion can give students the false impression that the religion life of humankind is insignificant or important. Failure to understand even the basic symbols, practices and concepts of the various religions makes much of history, literature, art and contemporary life unintelligible. Additionally knowledge of the roles of religion in the past and present promotes cross-cultural understanding essential to democracy and world peace. Study of religion is also important if students are to value religion liberty. (www.oup.usa.org.oxford).

Mojoyinola (2014) emphasized that health giver (social workers, nurses, doctors, health educators etc.) should help physically or mentally - ill patients find meaning in their sufferings by allowing the patients to exercise their spiritual beliefs or faith; meditate and pray according to their religions, or be prayed for by their religious leaders when they make such a request and should also allow the patients to read their religious books. Akinpelu (2005) reiterated that the most important role of religion is supplying what science and technology has proved unable to give, the meaning and essence of living and the ideal way to live for.

\subsection{Trends in National Certificate in Education (NCE) Programme in Nigeria}

The colleges of Education are the train the teachers colleges established to train and equipped teachers for their esteemed functions. The college of education awards the National Certificate in Education (NCE). This is generally a three year course of study in chosen discipline. In addition to classroom work, students are required to do a mandatory four months teaching practice in an assigned school. There are 161 colleges of education in Nigeria as at June 2017. As a means of improving primary education in Nigeria, the Ashby commission recommends the establishment of Grade 1 colleges for training of well qualified teachers for this important level of education. However, rather than implement the recommendation, government modified it to give birth to NCE programme for the preparation of teachers for the lower classes of secondary school and teacher training colleges. Therefore it could be said that original goal of the NCE was to prepare teachers for the secondary schools and not primaries. At any rate, the recent decision to make NCE the minimum teaching qualification in primary schools could be regarded as a return to original recommendation by Ashby commission (Aknibote, 1999).

\section{Minimum Standards for National Certificate in Education (NCE) Programme}

The question of minimum standards in the Nigerian educational system has been a critical national issue since early 70's when, after the Nigerian civil war, government took over schools from voluntary agencies. The society began to express dissatisfaction with the existing education system and the concept of falling standards in our educational system crept in. The Nigerian Federal government (FRN) in recognition of this observation articulated its stand on the issue in the national policy on education document. Federal government of Nigeria stated that any existing contradictions, ambiguities and lack of uniformity in the educational practices in different parts of the country should be removed to facilitate an even orderly 
development Federal Republic of Nigeria (1998); Federal Republic of Nigeria (2009); Federal Republic of Nigeria (2012) has it that transformation agenda for the present administration and wide spread criticism that the existing teacher education (NCE programme) is tunnel vissioned, the national commission for colleges of education has revised and updated the existing NCE minimum standards in colleges of Education in Nigeria (FRN, 2012). The curriculum content in colleges of education and university undergraduate programme tend to be inadequate for the demands of a knowledge economy (FRN, 2009). The first minimum standards document was produced by NCCE in 1990. The document has to be reviewed after five years and the most current was published in 2012.

The 2012 minimum standard documents were based on the new mandate of the teacher training programme at the NCE level which is the recognized minimum teaching qualification in Nigeria. The new mandate was to produce quality teachers for the Basic Education Subsector which encompasses the following categories of education:

1. Early childhood care, development and education

2. Kindergarten education.

3. Primary education

4. Junior secondary education.

5. Adult and non-formal education.

\section{Education and Self Reliance}

The oxford Advanced learner's dictionary explains self reliance to mean ability to do or decide things by oneself rather than depending on other people for help.

The concept of education for self reliance is also about self confidence, independence, responsibility and democratic involvement. The general objectives of education for self reliance are to equip learners with knowledge, skills and attitudes for tackling societal problems: to prepare youth for work in predominantly agricultural society and to enable learners know, appreciate and develop a culture that preserves the national tradition of education, individual freedom, responsibility, tolerance and respect.

Innocent (2016) contends that for education to bring about self reliance:

- Education should be of relevant to the society

- Educated individual must serve the society

- Education must be problem solving and

- $\quad$ Education must be work oriented.

In corroboration of the above, Nyerere (1967) opined that education for self reliance must teach a sense of commitment to the general society and help the society to accept standards suitable for a better future not those appreciated to the colonial past. He also advocates for a method of learning by doing, but such learning by doing must be directed towards a productive, constructive or creative end which should lead in the long run to solving problems of the society. He added that education should not be limited to training in basic skills but should include acquiring those habits which makes him or her virtuous. These virtues will make him or her religious minded, courageous, truthful, good - natured and the like. In a nut shell education for self reliance in Nyerere's viewpoint is a practical oriented education meant to provide real solutions to the societal needs.

\section{Islamic Studies as a discipline at the NCE Programme}

Islamic Studies as a discipline could be conceived as a process by which the knowledge of Islamic religious sciences is transmitted to learners using professionally approved method of teaching (Oladosu, 2007). While Islamic education refers to the totality of the upbringing of individual within the content and context of Islam. Islamic Studies consists of the study of Islam which encompasses everything from the different branches of Islamic law, languages, medicine, sciences and economics etc. In his work, Islamics: the conflux of Disciplines" (Oloyede, 2012) captured Islamic Studies as an academic discipline that is expected to study, analyze, utilize and develop Islam for the improvement of the understanding and application of the derivatives of Islam to the advantage of humanity and its complex dynamic environment. Its object is a balance interaction between the belief system, the knowledge system and the value system, the three of which interlock, interdependent and interconnect the nucleons of which is Islamic Studies. 


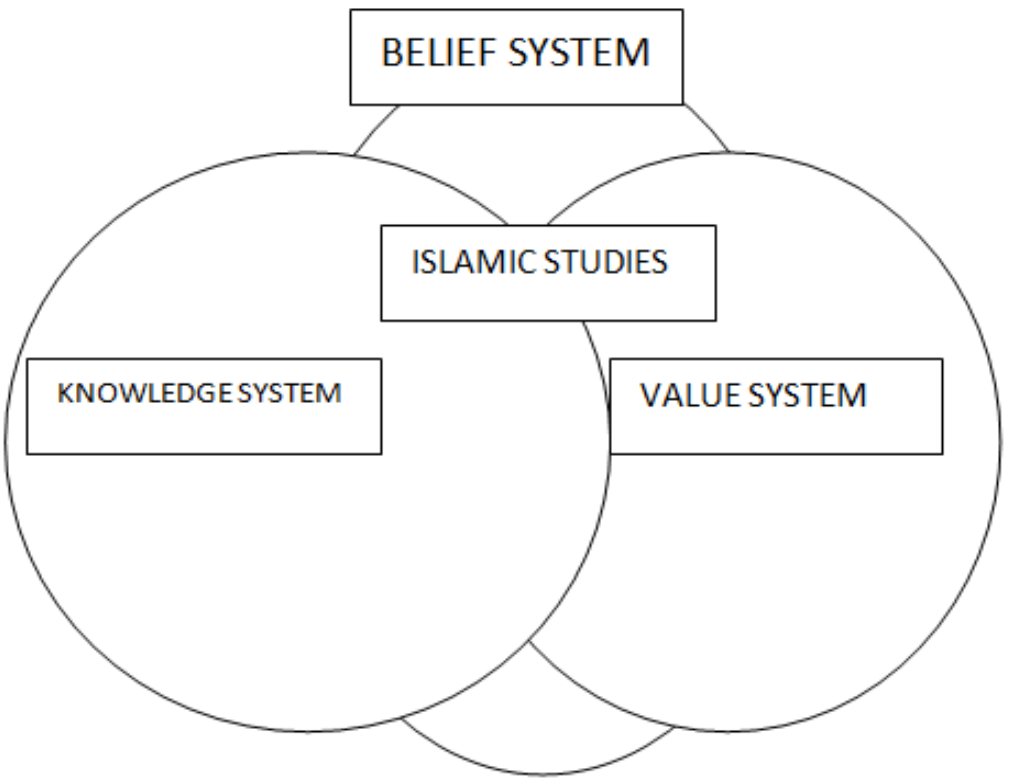

Figure-1.1. The symbol of belief, knowledge and value system in Islamic Studies. Source: Oloyede (2012).

The capture of Oloyede on Islamic Studies as an academic discipline is not far from the educational objective of Islamic Studies at the NCE level and among which are:

- $\quad$ To acquaint the students with broad outlines of Islam

- To prepare the students to understand Islam as a culture and civilization

- To provide high quality training to enable graduates make rigorous and scholar approach to the contemporary problems of the Muslim community with particular reference to Nigeria

- To instil in the students the spirit of God consciousness, to lead them to appreciate and uphold the values and teachings of Islam and live by it.

In addition the NCCE minimum standard also stipulates that Islamic Studies as a single major subject may be combined with any of the following subject: English, Hausa, Yoruba, Igbo, Social Studies, Arabic, Special Education (FRN, 2012).

\subsection{Factors Hindering Self Reliance among NCE Graduates of Islamic Studies}

Review of literature in the previous sections reveals among other things that for education to bring about self reliance, the educative process must involve not only training in specific skills and techniques through a method of practical work geared towards problem solving, but must also acquire those habits which will make him or her virtuous, religious minded, truthful, good natured and the like. However, attainment of self reliance among graduates of Islamic Studies is hindered by the following factors:

- Irrelevance of curriculum to societal need: the curriculum content of Islamic Studies at the NCE programme focuses mainly on the spiritual aspect of education. It emphasis spirituality whereas Islamic Studies curriculum was to cater for both spirituality and mundane life of man because Islam is all encompassing. The curriculum content is not adequate to meet their immediate and future needs and cannot enhance the attainment of self reliance among Islamic Studies graduates in a knowledge based economy. Therefore there is the need for Muslim educators, policy makers and curriculum development experts to be responsive to the needs of Islamic Studies students in coping with modern technological advancement and globalization of knowledge.

- Lack of information and communication Technology facilities: The method of delivery at this level of education is traditional and obsolete and the reasons for this are multidimensional. There are no ICT devices to teach Islamic Studies in tertiary institutions and in some cases where they are available, the teacher lack the skill to make use of them in the teaching and learning process. So there is urgent need for stakeholder in academics and Islamic Studies lecturers in particular to be ICT compliance.

- Lack of adequate manpower: lack of adequate manpower is one of the problems confronting Islamic Studies at the NCE level opinion of lectures from different colleges of education in South - West confirmed that a lecturer may take 8-11 courses as a result of inadequate manpower which often resulted to inefficiency and inadequate knowledge delivery.

- Lack of learning materials: Most of the books in the colleges of education are nothing to write home about. The books are outdated and not relevant to the needs of the students and modern 
society. Therefore there is need to equip the library with relevant books and other learning materials that can facilitate efficient and effective knowledge delivery.

- Poor Attitude of Lecturers towards Research: Lecturers attitude towards research is not encouraging at all due to the non conductive atmosphere. As a result, lecturers only come to the school to teach their course and leave. Abdulhamid (2017) opined that research findings can liberate man from the restraints and limitations of ignorance and dependency through exposure. The advanced countries of the world like Japan, America, etc are flourishing economically because of their exposure to research. It is note - worth to mention that without meaningful research in the academic Nigeria cannot develop as a nation and the graduates of tertiary institutions may not attain self reliance.

- Unemployment and low enrolment of Students: Various industries cannot employ the graduates of Islamic Studies because they are not relevant to the job demand of industries and in some cases where they are employed, they are paid low salary. On the part of the students, there is the fear of job prospects because many of them do not see the reason why they should go to higher institution to study Islamic Studies which they think cannot earn them any good job in future. As a result of this, students want to study courses which promise lucrative jobs after the completion of their courses. These account for the low enrolment of students for Islamic Studies. This issue needs to be addressed because it is threatening the job security of teachers teaching the subject at the various level of education.

- Lack of Funds: The non availability of enough funds for colleges of education is a contributory factor towards non attainment of self reliance among its graduates.

The government needs to provide from time to time funds for the review of the curriculum of Islamic Studies to accommodate oriented skills, creative arts, calligraphy, vocational courses and Islamic financial courses which are lucrative and through which they can gain economic empowerment. In addition, government should also make provision for implementation and monitoring of the curriculum through the accreditation exercises. If all these are implemented, it will bring about self reliance among the graduates of Islamic Studies (Alumode \& Nwite, 2016).

\subsection{Islamic Studies and Curriculum Innovation towards the Attainment of Self Reliance}

In view of the factors hindering the attainment of self reliance among the NCE graduates of Islamic Studies as highlighted above, it is deem necessary to review the curriculum through the process of curriculum innovation to accommodate oriented skills, vocational courses and agriculture which is the future of the country since the country is diversifying from crude oil to Agriculture so that the students can be adequately prepared for socio-economic needs of the society towards the attainment of self reliance.

According to Kolawole (2006) curriculum innovation takes place when an existing curriculum is to be reworked to make it relevant and meet the needs and aspirations of the society. This takes place when there are new information, knowledge and skills to be catered for by education. Curriculum innovation takes place with a view to making the curriculum continually relevant to the life of the society which it was dev eloped in the first instance. It is on this premise that resolved that with the expansion of knowledge and changes in culture over the ages, the task of selecting what to teach has become more and more complex and curriculum development has gradually evolved into an educational science in its own right. He also revealed that a concern for relevance of education to modern life is engendered by the fear that older curriculum quickly becomes obsolete and irrelevant because of rapid modernization. It leads to advocacy of the curriculum that is based on social process and life functions where knowledge is created, transmitted and used more effectively by individuals, enterprises, organizations and communities to promote economic and social development.

Based on the analysis given above, some scholars views on what should constitute the contents of Islamic Studies towards the attainment of self reliance are noted and discussed below:-

Habib (2015) and Dogarawa (2010) opined that Islamic Studies should be seen as an avenue for strengthening the human capacity of students and this may be achieved when the mission, vision, and the entire curriculum are reviewed and integrated with human capacity development programme. Every efforts should be taken whether formally or informally and whether individually or collectively to develop the skills and abilities of the students to be self reliance. Salako (2014) considers that the content of Islamic Studies that can enhance self reliance among its graduates should include fiqh and jurisprudence, Islamic History, Islamic social laws, Islamic finance, Arabic Grammar, Sciences, crafts and industries.

Susan and Muunir (2004) contend that the dynamics of knowledge acquisition in early civilization provided for a concept of Islamic education that provided no barrier between religious and secular learning. Lemu (2002) specifies that the curriculum of any subject Islamic Studies inclusive should prepare students for holistic development whereby the students would have the benefit of gaining economic empowerment so that they can be useful to themselves and the society.

It can be deducted from the submission of the above scholars that Islam is all encompassing and do not separate the spiritual life of a man from his mundane life. Therefore, the curriculum of Islamic Studies should be reviewed in the light of strategic planning, social networking, modern technology advancement and 
globalization of Islamic knowledge towards the attainment of self reliance among the NCE graduates of Islamic Studies.

\subsection{Conclusion and Recommendation}

The paper x-rays the importance of Islamic education in the society and national development in the past and in our contemporary society of the knowledge based economy. Among the aims and objectives of Islamic Studies at the NCE level as revealed by the works is to create the awareness that Islamic education placed no barrier between "religious" and "secular" learning in the human enterprise of knowing and glorifying the creator, seeking knowledge and putting it to beneficial use in society. The graduates of Islamic Studies at NCE level find it difficult to attain self reliance in this globalised world as a result of the lack of knowledge of (ICT), inadequate learning and teaching materials, irrelevance of curriculum contents to societal needs to mention but few. Therefore the paper recommends that:

- Islamic Studies can be used as a foundation for a career in business, healthcare, law or journalism to enhance self reliant among the graduates and not limited to the teaching of rituals.

- Teachers should be provided with basic skills of teacher's education programme and opportunities to acquire relevant skills and attitudes.

- Traditional education should blend with modern one where feasible particularly in indigenous technology.

- Building up professional skills and knowledge which will permit students to pursue income generating activities after graduation and attain high standard of self reliance.

- Monitoring of the accreditation of NCE programme and ensuring that the curriculum is implemented and reviewed in every five years.

- Workable and clearly defined curriculum innovation which is relevant to the concept of self reliance should be pursed.

- Government should fund capacity building of academic staff in the areas of research and should also provide adequate finance for the review of the curriculum on regular basis.

- Finally, for Islamic Studies to be relevant subject in knowledge based economy the curriculum content should be rich, diversified and integrated with other subjects and sciences and other contents that are of immense contribution to the national development which at the same time would create rooms for employment opportunities for Islamic Studies graduates towards the attainment of self reliance.

\section{References}

Abdulhamid, R. (2017). Challenges and prospects in studying of Islamic studies in the university of Abuja in augustus (ed). Abuja Journal of Philosophy and Religion, 4, 115-127.

Akinpelu, J. A. (2005). Essays in philosophy and education. Ibadan, Oyo State, Nigeria: Stirling-Publishers.

Aknibote, O. (1999). N.C.E teacher education programme for Nigerian primary schools: Expectations for the twenty-first century in abimbade (E.d) teaching and teacher preparation in twenty-first century. Ibadan, Nigeria: Published by Department of Teacher Education, University of Ibadan.

Alumode, B. E., \& Nwite, O. (2016). Minimum standards and accountability in colleges of education. British Journal of Education, 4(5), 53 -62.

Babarinde, K., \& Bankole, A. (2011). Society, political economy and education in Obanya. Jericho_Ibadan: Evans Bothers Publisher.

Dogarawa, A. B. (2010). Combating poverty through self reliance: The Islamic approach.

Federal Republic of Nigeria. (1998). National policy on Education. Lagos: Government Press.

Federal Republic of Nigeria. (2009). National teacher education policy. Abuja Federal: Ministry of Education.

Federal Republic of Nigeria. (2012). Nigeria certificate in education minimum standards. National Commission for Colleges of Education.

Federal Republic of Nigeria. (2014). National policy on Education.

Habib, A. G. (2015). Strengthening the human capacity of the Muslim Youth through the Makarantar Allo (elementary stage of Islamic education) for self-reliance, poverty alleviation and national development. Journal of Emerging Trends in Educational Research and Policy Studies, 6(7), 249-253.

Kolawole, C. O. O. (2006). Curriculum design implementation \& innovation. Ibadan cultural studies group, faculty of arts. Nigeria: University of Ibadan.

Lemu, A. (2002). Teacher for tolerance and freedom of religion or belief. Report from the Preparatory Seminar Held in Osio December 7 - 92002.

Mojoyinola, J. A. (2014). Spirituality: The "what", "why" and how in social work. A Faculty Lecture, Faculty of Education University of Ibadan.

Nyerere, J. (1967). Education for self reliance.

Oladosu, A. G. A. (2007). Education crises in Nigeria the perspective of Arabic Education in M. A. Muhibbudin (Ed) education crisis in Nigeria. Arabic and Islamic Studies perspectives in Nigeria: Shebiomo Publication.

Oloyede, I. O. (2012). Islamics: The conflux of disciplines, inaugural lecture university of Ilorin. 
Salako, T. A. (2014). An analysis of factors responsible for dwindling of students in Islamic studies among Senior Secondary Schools in Ogun State Nigeria. Unpublished PhD Thesis Submitted to the Faculty of Education, International Islamic University, Malaysia.

Sheikh, M. S. (1997). Studies in Muslim philosophy SH. Lahore Pakistain: Muhammed Ashraf Publisher.

Susan, L. D., \& Muunir, A. S. (2004). Defining Islamic education: Differentiation and application in current issues in comparative education: Teachers' College, Columbia University. 